\title{
Complement activation in thrombotic microangiopathy
}

\author{
D. Karpman; R. Tati* \\ Department of Paediatrics, Clinical Sciences Lund, Lund University, Sweden
}

\section{Keywords \\ Complement}

\section{Summary}

The endothelium lining the vascular lumen is continuously exposed to complement from the circulation. When erroneously activated on host cells, complement may generate a deleterious effect on the vascular wall leading to endothelial injury, exposure of the subendothelial matrix and platelet activation. In this review the contribution of complement activation to formation and maintenance of the pathological lesion termed thrombotic microangiopathy (TMA) is discussed. TMA is defined by vessel wall thickening affecting mainly arterioles and capillaries, detachment of the endothelial cell from the basement membrane and intraluminal thrombosis resulting in occlusion of the vessel lumen. The TMA lesion occurs in haemolytic uraemic syndrome (HUS) and thrombotic thrombocytopenic purpura (TTP). HUS is further sub-classified as associated with Shiga toxin-producing Escherichia coli (STEC-HUS) or with complement dysregulation (atypical HUS) as well as other less common forms. The contribution of dysregulated complement activation to endothelial injury and platelet aggregation is reviewed as well as specific complement involvement in the development of HUS and TTP.

Korrespondenzadresse

Diana Karpman, MD PhD

Department of Paediatrics, Clinical Sciences Lund Lund University

Lund, Sweden

Tel. +46/46/222 0747, Fax +46/46/222 0748

E-mail: diana.karpman@med.lu.se

Figure 1 and Table 1 are part of the PhD thesis of Dr. Ramesh Tati.

\section{Schlüsselwörter \\ Komplement}

\section{Zusammenfassung}

Das Endothel, die zum Lumen ausgerichtete Gefäßinnenwand, ist im ständigen Kontakt mit zirkulierenden Komplementfaktoren. Wenn Komplement irrtümlich auf Wirtszellen aktiviert wird, kann es eine zerstörerische Wirkung auf die Gefäßwand auslösen, die zu Endothelschädigung, Exposition der subendothelialen Matrix und Thrombozytenaktivierung führt.

In dieser Übersicht wird der Beitrag diskutiert, den die Komplementaktivierung zur Entstehung und Aufrechterhaltung der pathologischen Läsion, der so genannten thrombotischen Mikroangiopathie (TMA), leistet. Die TMA ist definiert durch eine vorwiegend arterioläre und kapilläre Gefäßwandverdickung, Ablösung der Endothelzellen von der Basalmembran und Thrombosierung des Lumens, die zum Gefäßverschluss führt. Die TMA-Läsion tritt bei urämisch-hämolytischen Syndrom (HUS) und thrombotisch-thrombozytischer Purpura (TTP) auf. HUS wird unterteilt in mit Shiga-Toxin-produzierende Escherichia coli assoziierte HUS (STEC-HUS) und mit Komplementregulationsstörung assoziierte HUS (atypische HUS) sowie andere seltene Formen. Wir betrachten den Anteil, den eine Fehlregulation der Komplementaktivierung bei der Endothelschädigung und der Thrombozytenaggregation hat, sowie die spezifische Beteiligung des Komplements bei der Entstehung von HUS und TTP.

Komplementaktivierung bei thrombotischer Mikroangiopathie

Hämostaseologie 2013;33:-

DOI: 10.5482/HAMO-12-12-0025

received: December 22, 2012

accepted in revised form: January 23, 2013

prepublished online: February 15, 2013
The main functions of the complement system are disposal of foreign cells, such as bacterial pathogens, or altered host cells, such as apoptotic cells, by opsonization and cytolysis. Upon activation complement components are released with anaphylatoxic, anti-microbial and chemotactic properties. Complement activation is strictly controlled by numerous regulators to prevent undesirable activation on host cells. In spite of this massive regulation complement may become activated on host cells, with deleterious effects, in various infectious, genetic and autoimmune diseases. In these conditions complement activation either overwhelms the regulators, or the regulators are dysfunctional, thus allowing inappropriate activation to harm host cells. Two such conditions are reviewed here: - haemolytic uraemic syndrome (HUS),

- thrombotic thrombocytopenic purpura (TTP).

Activation of the complement cascade in HUS was demonstrated in the 1970-80s (1). HUS is a syndrome associated with

- non-immune haemolytic anaemia,

- thrombocytopenia,

- acute renal failure,

- thrombotic microangiopathy (TMA) lesions in the renal glomeruli.

The quest to understand how complement activation was involved in this syndrome led to the finding that some patients had mutations in the main fluid phase complement regulator factor $\mathrm{H}(2,3)$.

The form of disease primarily associated with complement dysregulation is known as atypical HUS (aHUS). Since the initial finding many mutations in complement regulators and factors have been described, as well as autoantibodies to factor $\mathrm{H}$, and various mechanisms by which complement activation can cause and/or con- 
tribute to the development of aHUS have been described.

There is evidence for complement activation even in the other main form of HUS, caused by Shiga toxin-producing Escherichia coli (STEC) infection. In this subtype of HUS complement activation appears to be secondary to the primary toxininduced endothelial cell injury and platelet activation. Nonetheless, complement activation may potentially contribute to disease progression.

Likewise, complement is activated during TTP. TTP similarly manifests as:

- non-immune haemolytic anaemia,

- thrombocytopenia,

- renal manifestations,

- neurological manifestations,

- fever.

TTP is associated with deficiency or dysfunction of the von Willebrand factor (VWF)-cleaving protease ADAMTS13 due to mutations or auto-antibodies. The pathological lesion in HUS and TTP, termed TMA, is very similar. In this review the mechanisms leading to the development of
HUS and TTP will be described with reference to the contribution of complement activation.

\section{The complement system}

The complement system plays an important role in the host innate immune response. Activation of complement under physiological conditions will result in removal of foreign or unwanted cells and cellular debris, such as bacteria or apoptotic cells, and disposal of immune complexes. The complement system is comprised of three activation pathways defined as the classical, lectin and alternative pathways ( $\triangleright$ Fig. 1), varying with regard to the activating surface or molecule, and a common terminal pathway.

- The classical pathway can be activated by immune complexes, apoptotic cells, $\mathrm{C}$-reactive protein as well as other nonimmune activators (4).

- The lectin pathway is activated by the binding of ficolins and mannose-binding lectins (MBL) to the surface of pa- thogens and dying cells (5) and to polymeric IgA (6). The classical and lectin pathways converge at the formation of the C3 convertase C4b2a, capable of cleaving $\mathrm{C} 3$ into $\mathrm{C} 3 \mathrm{a}$ and $\mathrm{C} 3 \mathrm{~b}$. Binding of a $\mathrm{C} 3 \mathrm{~b}$ molecule to the $\mathrm{C} 3$ convertase forms the C5 convertase cleaving C5 into C5a and C5b.

- The alternative pathway is activated on the surface of foreign or altered host cells.

The alternative pathway undergoes constant low-grade activation in the circulation, so called tick-over by low-rate hydrolysis of $\mathrm{C} 3$ into $\mathrm{C} 3\left(\mathrm{H}_{2} \mathrm{O}\right)$. In the presence of $\mathrm{Mg}^{2+} \mathrm{C} 3\left(\mathrm{H}_{2} \mathrm{O}\right)$ interacts with factor $\mathrm{B}$, cleaved by factor $\mathrm{D}$ into $\mathrm{Bb}$, thus forming $\mathrm{C} 3\left(\mathrm{H}_{2} \mathrm{O}\right) \mathrm{Bb}$. This initial form of the $\mathrm{C} 3$ convertase cleaves $\mathrm{C} 3$ into $\mathrm{C} 3 \mathrm{a}$ and $\mathrm{C} 3 \mathrm{~b}$. Cleavage into $\mathrm{C} 3 \mathrm{~b}$ exposes cell-binding sites allowing covalent binding to cell surfaces (7). C3b binding to factor B will form the $\mathrm{C} 3$ convertase $(\mathrm{C} 3 \mathrm{bBb})$ and promote more cleavage of $\mathrm{C} 3$. The convertase is stabilized by binding to properdin. The

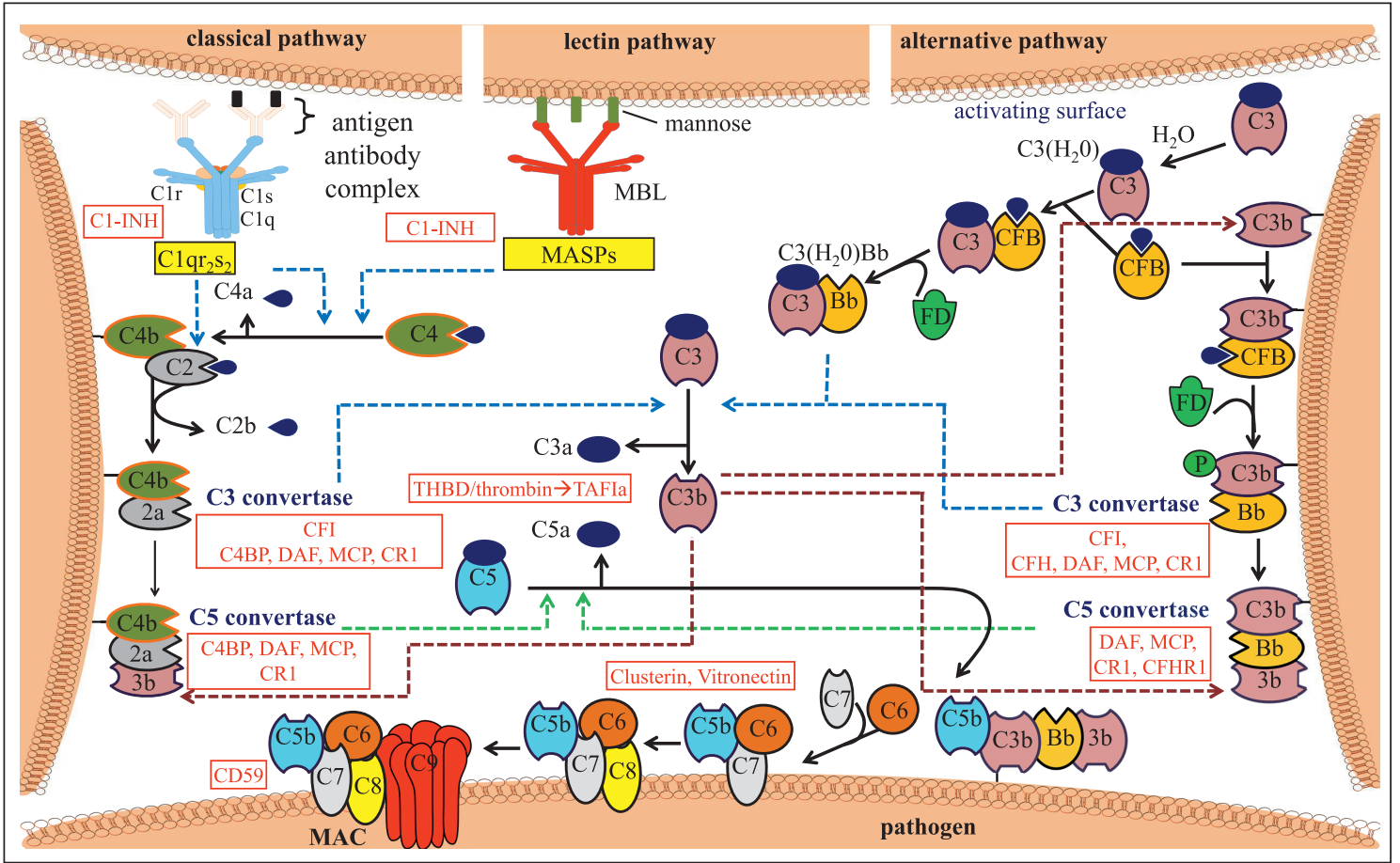

Fig. 1 The classical, lectin and alternative pathways of complement activation. Complement activation occurs on the surface of foreign cells and altered host cells. Regulators are marked in red rectangles. CINH: C1 inhibitor; MBL: mannose-binding lectin; MASP: MBL-associated serine protease; CFB: factor B; FD: factor D; P: properdin; THBD: thrombomodulin (in complex with thrombin); TAFla: thrombin-activatable fibrinolysis inhibitor; CFI: factor l; CFH: factor H; C4BP: C4 binding protein; DAF: decay accelerating factor; MCP: membrane cofactor protein; CR1: complement receptor 1, MAC: membrane attack complex 
Tab. 1 Inhibitors of the complement system

\begin{tabular}{|c|c|c|c|c|}
\hline \multicolumn{2}{|l|}{ complement } & \multirow{2}{*}{$\begin{array}{l}\text { fluid-phase or } \\
\text { membrane-bound }\end{array}$} & \multirow[t]{2}{*}{ mechanism of inhibition } & \multirow[t]{2}{*}{ reference } \\
\hline regulator & pathway & & & \\
\hline factor $\mathrm{H}$ & alternative & fluid phase & $\begin{array}{l}\text { cofactor for factor I in cleavage of C3b; accelerates decay of the } \\
\text { C3 convertase and preferentially recognizes host cells }\end{array}$ & (95) \\
\hline factor H-related protein 1 & terminal & fluid phase & inhibits the $\mathrm{C} 5$ convertase & (96) \\
\hline factor I & $\begin{array}{l}\text { alternative and } \\
\text { classical }\end{array}$ & fluid phase & $\begin{array}{l}\text { cleaves } \mathrm{C} 3 \mathrm{~b} \text { or } \mathrm{C} 4 \mathrm{~b} \text { to the inactive forms in presence of cofactors } \\
\text { factor } \mathrm{H}, \mathrm{C} 4 \text { binding protein, MCP or CR1 }\end{array}$ & (97) \\
\hline CD46 (MCP) & $\begin{array}{l}\text { alternative, classical } \\
\text { and terminal }\end{array}$ & membrane-bound & cofactor for factor I in cleavage of $\mathrm{C} 3 \mathrm{~b}$ & (98), (99) \\
\hline thrombomodulin & $\begin{array}{l}\text { alternative, classical } \\
\text { and terminal }\end{array}$ & membrane-bound & $\begin{array}{l}\text { enhances factor I-mediated inactivation of } \mathrm{C} 3 \mathrm{~b} \text { in the presence } \\
\text { of factor } \mathrm{H} \text {; generation of TAFla }{ }^{1} \text {, which inactivates } \mathrm{C} 3 \mathrm{a} \text { and } \mathrm{C} 5 \mathrm{a}\end{array}$ & $(100)$ \\
\hline C1-inhibitor & classical and lectin & fluid phase & $\begin{array}{l}\text { binds to } \mathrm{C} 1 \mathrm{r} \text { and } \mathrm{C} 1 \mathrm{~s} \text { removing them from } \mathrm{C} 1 \mathrm{q} \text {, or binds to } \\
\text { MASPs }\end{array}$ & (101) \\
\hline C4 binding protein & $\begin{array}{l}\text { classical, lectin and } \\
\text { terminal }\end{array}$ & fluid phase & $\begin{array}{l}\text { decay accelerating activity (C3 and C5 convertases) and cofactor } \\
\text { for factor I }\end{array}$ & (102) \\
\hline $\begin{array}{l}\text { complement receptor } 1 \\
\text { (CR1, CD35) }\end{array}$ & $\begin{array}{l}\text { alternative, classical } \\
\text { and terminal }\end{array}$ & membrane-bound & decay accelerating activity and cofactor for factor I & (103) \\
\hline CD55 (DAF) & $\begin{array}{l}\text { alternative, classical } \\
\text { and terminal }\end{array}$ & membrane-bound & inhibits assembly and promotes decay of $\mathrm{C} 3$ and $\mathrm{C} 5$ convertases & (104) \\
\hline clusterin & terminal & fluid phase & inhibits MAC formation & (59) \\
\hline vitronectin & terminal & fluid phase & inhibits MAC formation & (105) \\
\hline CD59 & terminal & membrane-bound & inhibits MAC formation & (106) \\
\hline carboxypeptidase $\mathrm{N}$ & $\begin{array}{l}\text { alternative and } \\
\text { terminal }\end{array}$ & fluid phase & cleavage and partial inactivation of $\mathrm{C} 3 \mathrm{a}$ and $\mathrm{C} 5 \mathrm{a}$ & (107) \\
\hline
\end{tabular}

MCP: membrane cofactor protein; DAF: decay accelerating factor; MAC: membrane attack complex; MASP: mannose-binding lectin-associated serine protease; TAFI: thrombin-activatable fibrinolysis inhibitor; ${ }^{1}$ Thrombomodulin is a cofactor for thrombin-mediated activation of TAFI to TAFla. TAFla is a plasma procarboxypeptidase B that inactivates C3a and C5a by removal of an arginine.

reaction is amplified by further binding of factor B to C3b.

Thus, after C3b is formed, activation of all pathways of complement can be enhanced through the amplification loop of the alternative pathway.

Binding of a molecule of $\mathrm{C} 3 \mathrm{~b}$ to the $\mathrm{C} 3$ convertase $(\mathrm{C} 3 \mathrm{bBb})$ will also form the $\mathrm{C} 5$ convertase thus cleaving $\mathrm{C} 5$. C5b binds to C6 and C7 and attaches to the cell wall (8). This is followed by binding of $\mathrm{C} 8$ and numerous $\mathrm{C} 9$ molecules to form the $\mathrm{C} 5 \mathrm{~b}-9$ lytic complex, also known as the membrane attack complex (MAC). The C9 molecules surround a pore in the cell membrane thus causing cell lysis when sufficient C5b-9 structures are formed ( Fig. 1).

Complement possesses other potent effects, in addition to cell lysis. Peptides gen- erated during activation, i.e. C3a, C4a and C5a, possess antimicrobial and/or anaphylatoxic and chemotactic properties. Furthermore, $\mathrm{C} 3 \mathrm{~b}, \mathrm{iC} 3 \mathrm{~b}$ and $\mathrm{C} 4 \mathrm{~b}$ binding to cells function as opsonins allowing these cells to undergo phagocytosis.

It is thus evident that complement is a very powerful system that, upon full-blown activation, removes foreign and apoptotic cells by induction of

- inflammation,

- phagocytosis and

- cell lysis.

Left unchecked this system could be damaging to healthy host cells, especially as the alternative pathway undergoes constant low-rate activation. To prevent this, multiple complement regulators function on the cell surface and in the fluid phase.

\section{Regulation}

Activation of the complement system is tightly regulated. The regulators inhibiting the various pathways are shown ( Fig. 1) and listed ( Tab. 1). The main fluid phase regulator functional in the alternative pathway is factor $\mathrm{H}$ possessing three regulatory mechanisms:

- cofactor to factor I in cleavage of C3 to iC3b,

- prevention of formation and accelerated decay of the convertase ( $\mathrm{C} 3 \mathrm{bBb})$,

- host recognition, i.e. discrimination between host and foreign cell surfaces based on the presence of polyanions such as glycosaminoglycans and sialic acids on host cell surfaces (9).

Factor $\mathrm{H}$ will thereby preferentially bind to non-activating surfaces, such as host cells, and thus complement activation via the 
alternative pathway will be prevented. Foreign cells, lacking polyanions on their surface, will be susceptible to the destructive effects of complement as they do not bind factor $\mathrm{H}$.

Complement activation may play an important role in the evolvement of thrombotic lesions.

Overwhelming or dysregulated complement activation may enhance and maintain

- endothelial injury,

- neutrophil chemotaxis and

- platelet activation.

Complement activation in thrombotic microangiopathy (TMA) will thus promote thrombosis and sustain formation of the lesion.

\section{Thrombotic microangiopathy}

TMA defines a pathological lesion consisting of

- vessel wall thickening, primarily affecting arterioles and capillaries, with swelling or detachment of the endothelial cell from the basement membrane,

- accumulation of hyaline amorphous material in the subendothelial space,

- intraluminal thrombosis and partial or complete occlusion of the vessel lumen (10).

Endothelial cell injury in the microvasculature and platelet activation are central to the pathogenesis of TMA. Several clinical syndromes are associated with the TMA lesion, predominantly affecting the kidney. These include HUS and TTP.

- HUS is classified based on etiology into various subtypes (11) of which two major subtypes are

- STEC-HUS, also called typical HUS $(12,13)$ and

- aHUS associated with complement dysregulation secondary to $\mathrm{mu}$ tations or autoantibodies as described (14).

- TTP is associated with deficiency or dysfunction of ADAMTS13, the von Willebrand factor (VWF)-cleaving pro- tease, due to a genetic or acquired disorder $(15,16)$.

\section{Complement activation in TMA}

Complement activation may occur as the primary event leading to endothelial perturbation and platelet activation (in aHUS) or as a secondary event associated with thrombus formation after toxin-mediated injury (STEC-HUS) or due to ADAMTS13-deficiency (TTP).

In aHUS endothelial damage and platelet activation are primarily associated with dysregulated complement activation allowing the harmful effects of complement to occur on host cells (17-19). Complement activation during STEC-HUS is principally associated with endothelial cell injury induced by bacterial virulence factors Shiga toxin and lipopolysaccharide and enhanced by the host response (20, 21). Endothelial disruption may, in turn, lead to platelet activation, or platelets may be directly activated by the toxin (22).

In TTP ultra-large forms of VWF circulate due to deficiency or dysfunction of ADAMTS13. Complement activation can occur as a secondary phenomenon related to endothelial injury and thrombus formation (23). Thus, although the TMA lesion is similar in these three conditions (STEC-HUS, aHUS and TTP), the triggering event leading to lesion formation and complement activation differs.

\section{Complement activation on endo- thelial cells and platelets and its role in TMA}

Intact endothelium allows normal blood flow and homeostasis. Endothelial cells separate the vascular space from the extravascular tissue. Endothelial cells express heparan sulphate and release thrombomodulin and tissue factor inhibitor thus preventing clot formation $(24,25)$. Endothelial activation and/or injury promotes

- leukocyte rolling and migration,

- platelet aggregation,

- loss of thromboresistance.

Stimulation of endothelial cells with IL-1, mimicking inflammation, generates a procoagulant state characterized by increased synthesis of tissue factor and plasminogen activator inhibitor and decreased thrombomodulin activity (26).

During the inflammatory process the endothelium is targeted by the complement system. Tissue factor expression and release by endothelial cells is regulated by complement and mediated by IL-1 $\alpha$ (27). Endothelial cells express and secrete complement factors and regulators as well as receptors $(28,29)$. Complement activation on the endothelium will lead to cell activation, with subsequent

- expression of adhesion molecules (30, 31 ,

- release of cytokines and chemokines (32-35),

- release of cell-derived microparticles (36),

- MAC formation and ultimately cytolysis.

$\mathrm{C} 3 \mathrm{a}$ and $\mathrm{C} 5 \mathrm{a}$ released during activation of the complement cascade bind to endothelial cells and induce cytokine release (37, 38). C5a and IL-8 (upregulated in the endothelium) are chemotactic for polymorphonuclear leukocytes. Vascular permeability is increased by activation of the kinin and complement systems on the endothelium (39) attributed in part to C3a and C5a (25) as well as the terminal complement complex, C5b-9, which also induces increased endothelial permeability (40) allowing leukocyte migration into the extravascular space (41). Thus, complement activation on the endothelium during the inflammatory process promotes cell injury and enhances vascular permeability as well as leukocyte recruitment to the vascular wall and underlying tissues.

Endothelial cell activation and damage has been documented in TMA as well as the interaction of endothelial cells with complement.

Shiga toxin has a direct cytotoxic effect on endothelial cells (21).

The toxin was also shown to induce the expression of $\mathrm{P}$ selectin on microvascular endothelial cells thus binding $\mathrm{C} 3$, activating the alternative pathway and reducing thrombomodulin. This process promoted thrombus formation under perfusion con- 
ditions in vitro, and in a mouse model in vivo (42).

Atypical HUS mutations affecting complement factors $\mathrm{C} 3$ and factor $\mathrm{B}(43,44)$ as well as the main fluid-phase regulator factor $\mathrm{H}(17,18)$ allows unrestricted complement activation to occur on endothelial cells due to hyperfunction of $\mathrm{C} 3$ or factor $\mathrm{B}$ or decreased regulatory capacity of factor H. Glomerular endothelial cells stimulated with pro-inflammatory mediators (TNFa and IFN $\alpha$ ) and exposed to aHUS serum with hyperfunctional C3 expressed tissue factor and thus a procoagulant phenotype (43).

Serum from TTP patients with ADAMTS13 deficiency induced C3 deposition and MAC formation on microvascular endothelial cells and promoted neutrophil-mediated endothelial cytotoxicity. These effects were abrogated by complement inhibition (23). Taken together, there is in vitro and in vivo evidence for complement activation on endothelial cells in subtypes of TMA, which may initiate and sustain the endothelial cell injury.

Platelet activation during TMA may occur as a result of direct activation of platelets, or secondary to endothelial injury.

Platelets roll on the surface of activated endothelial cells and on VWF and collagen in the subendothelium exposed during perturbation of the endothelial lining (45). Platelets can bind $\mathrm{C} 3$ and $\mathrm{C} 4$, and express complement receptors $\mathrm{P}$ selectin and CR2, capable of binding $\mathrm{C} 3 \mathrm{~b}$ and $\mathrm{C} 3 \mathrm{~d}$, respectively (46-50), as well as CR4 (51), CR3 (52) and the $\mathrm{Clq}$ receptor (53). Binding of complement components from the alternative, classical and terminal pathway can activate platelets (54-57). The converse has also been reported, the complement system can become sequentially activated on platelets (46). To prevent excessive complement activation platelets express and bind complement regulators (58-64).

Thrombocytopenia occurring during TMA is a subsequence of platelet consumption in the microangiopathic lesion.

In STEC-HUS bacterial virulence factors Shiga toxin and lipopolysaccharide circu- late bound to platelets as well as to other blood cells $(22,65)$. Platelets are activated after binding Shiga toxin and/or lipopolysaccharide. Our group has demonstrated that activated plaletets form aggregates with leukocytes during STEC-HUS. Platelet- and monocyte-derived microparticles are thus released. Platelet-leukocyte aggregates as well as cell-derived microparticles were shown to be coated with complement C3 and C9 (66) suggesting complement activation on these blood cells. In aHUS platelet activation may occur as a result of complement-mediated endothelial injury (17) or due to complement activation on platelets as a result of dysfunctional inhibition (19) or hyperfunctional C3 (67). Atypical HUS-associated factor $\mathrm{H}$ mutations were shown to allow complement activation to occur on platelets thus leading to their activation (19). In TTP VWF-platelet strings are formed under perfusion in vitro due to lack of ADAMTS13 (68). Platelet and endothelial microparticles are released into the circulation $(69,70)$. Although complement activation has not been demonstrated on the VWF-platelet strings, or the microparticles, it is plausible to assume that complement activation occurs in the TTP setting of platelet activation on the endothelial surface. Thus in the various sub-forms of TMA complement activation can occur on the endothelium and platelet thrombi, and may thereby augment the process.

\section{Complement activation in the renal TMA lesion}

The TMA lesion affects renal glomerular capillaries. The glomerular vasculature and basement membrane are particularly vulnerable to complement activation. This may be due to the fact that the glomerular basement membrane is devoid of inherent complement regulators and thus dependent on soluble regulators $(71,72)$. Furthermore, glomerular endothelial cells are exposed to shear stress, which may have, together with nitric oxide, a role in regulating the permeability of the glomerular capillary wall (73). Shear stress affects the endothelium and platelets and unfolds VWF exposing the scissile cleavage site.
ADAMTS13 will normally dock onto VWF and cleave it into smaller multimers (74).

The glomerular endothelium may be particularly susceptible to injury in the TMA setting.

For example, renal glomerular endothelial cells are more susceptible to the cytotoxic effect of Shiga toxin due to increased basal expression of the Gb3 toxin receptor (75). Likewise, lack of functional ADAMTS13 at sites exposed to higher shear stress may promote thrombus formation when the endothelial layer is perturbed. Thus, the glomerular vasculature may be more prone to develop the TMA lesion and complement deposition on thrombi and injured endothelial cells.

\section{Complement activation in STEC-HUS}

There is clear evidence of systemic complement activation during STEC-HUS. Patients may exhibit low levels of serum C3 $(1,76)$ and elevated levels of complement products $\mathrm{C} 3 \mathrm{a}$, factor $\mathrm{Bb}$ and soluble $\mathrm{C} 5 \mathrm{~b}-9$ $(66,77)$, as well as complement C3 and C9 on platelet-leukocyte aggregates and cellderived microparticles, as described. In vitro studies have shown that Shiga toxin 2 can activate the alternative pathway of complement in serum and bind to factor $\mathrm{H}$ at host surface recognition sites thus inhibiting its regulatory effect (78). Furthermore, in vitro experiments showed that Shiga toxin (both 1 and 2) could induce the formation of platelet-leukocyte aggregates and the release of blood cell-derived microparticles, both coated with $\mathrm{C} 3$ and $\mathrm{C} 9$, an effect enhanced in the presence of $E$. coli O157 lipopolysaccharide (66).

Further support for the role of complement in STEC-HUS came from a report describing the successful use of eculizumab, an anti-C5 antibody approved for the treatment of aHUS, in three children with STEC-HUS and neurological complications (79). Based on this report approximately 200 STEC-HUS patients were treated with eculizumab during the large $E$. coli O104:H4 outbreak in Germany in 2011. Reports from this outbreak did not, however, demonstrate a beneficial effect of this treatment (80-82). This may be due to 
administration late in the course of disease. Thus, randomized clinical trials are required to determine if certain patients could benefit from this treatment and at which time point eculizumab should be administered.

\section{Complement activation in aHUS}

Atypical HUS (aHUS) has been associated with mutations in complement regulators factor $\mathrm{H}$, factor I, membrane cofactor protein (MCP, CD46), clusterin, thrombomodulin, or complement factors $\mathrm{C} 3$ or factor B $(14,83,84)$. Mutations are usually heterozygous and certain patients have mutations in more than one factor. Patients may have auto-antibodies to factor $\mathrm{H}$, which have been associated with deletions or rearrangements in factor $\mathrm{H}$ and factor $\mathrm{H}$-related proteins (CFHRs) resulting in hybrid genes. This form of HUS has been termed DEAP-HUS (DEficient for CFHR proteins and factor $\mathrm{H}$ Autoantibody Positive) (85). As described, the mutations have been shown to trigger complement activation thus leading to deposition on renal endothelial cells $(43,44)$ and patient platelets $(19,67,84)$. Patients may have C3 deposition in glomeruli ( Fig. 2) (86) suggesting that complement activation occurs systemically in the circulation and locally in the renal vasculature.

Patients with aHUS have benefited from treatment with eculizumab, monoclonal antibody targeting human C5, during relapses and prophylactically (87). This treatment has also proved to be efficient in preventing and treating recurrences of aHUS after renal transplantation (88). The efficacy of eculizumab in treating aHUS proves unequivocally the role of complement dysregulation in inducing this condition.

\section{Complement activation in TTP}

In TTP the kidney is affected with typical TMA lesions. Endothelial and platelet involvement occurs due to the release of ultra-large VWF multimers capable of binding platelets and consequently forming VWF-platelet aggregates which cannot be cleaved due to dysfunctional/deficient ADAMTS13, thus leading to thrombosis (89). Complement does not have an initiating role in this process but there is considerable evidence that complement activation occurs. Patients with TTP have elevated circulating C3a and soluble C5b-9

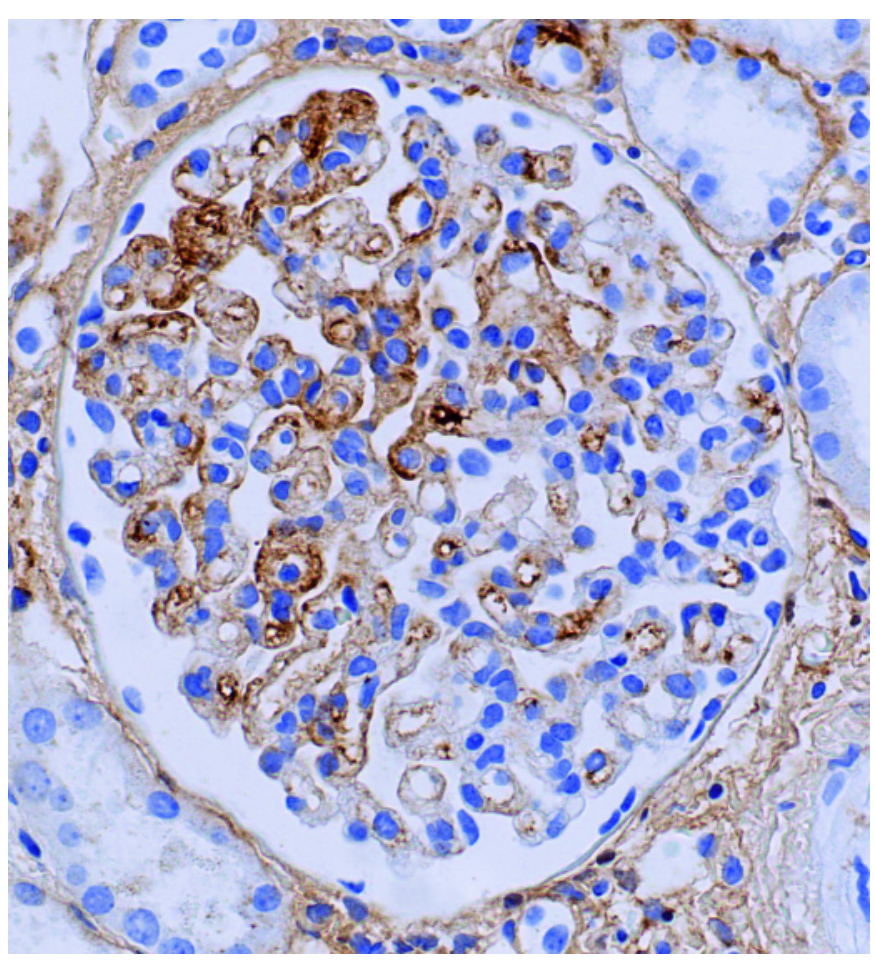

Fig. 2

Renal biopsy from a child with aHUS and mutations in $\mathrm{C} 3$ and MCP (86). C3 deposition (brown labeling) was demonstrated in capillaries and thrombi in glomeruli. The photomicrograph is available by courtesy of Dr. Sabine Leh, Department of Pathology, Haukeland University Hospital, Bergen, Norway during acute episodes (90) or low levels of C3 (91). Renal and myocardial tissue from TTP patients autopsied in the 70s showed complement deposition $(92,93)$. More recently complement C3d, C4d and C5b-9 were observed in the skin of a patient with acquired TTP (94). The patient described in this case report was successfully treated with eculizumab, also suggesting a role for complement activation in TTP in this case.

\section{Conclusions}

Although the TMA lesion observed in HUS and TTP is very similar, the primary cause of disease differs.

- In STEC-HUS the disease is initiated by gastrointestinal bacterial infection.

- In aHUS disease is initiated by complement dysregulation.

- In TTP the disease process is triggered by microvascular thrombosis induced by ADAMTS13 deficiency.

Thus, complement involvement is not a primary phenomenon in all cases. All the same, complement activation may contribute to sustaining the pathological lesion by enhancing endothelial damage, platelet activation and deposition of thrombi on the subendothelial matrix and basement membrane.

The beneficial effect of eculizumab in the treatment of aHUS suggests that targeting complement involvement in this subtype of HUS is essential for hindering disease development, whereas in the other forms of TMA alternative therapies should be designed in order to target the initial triggers of disease.

\section{Financial support}

Diana Karpman is supported by grants from The Swedish Research Council (K2013-64X-14008-13-5), The Torsten Söderberg Foundation, Crown Princess Lovisa's Society for Child Care, and The Konung Gustaf V:s 80-årsfond.

\section{Conflict of interest}

Diana Karpman was the national coordinator in Sweden of the multi-center inter- 
national trial of eculizumab (Alexion Pharmaceuticals) in patients with atypical haemolytic uraemic syndrome (2010).

\section{References}

1. Monnens L, Molenaar J, Lambert PH et al. The complement system in hemolytic-uremic syndrome in childhood. Clin Nephrol 1980; 13: 168-171.

2. Warwicker P, Goodship TH, Donne RL et al. Genetic studies into inherited and sporadic hemolytic uremic syndrome. Kidney Int 1998; 53: 836-844.

3. Ying L, Katz Y, Schlesinger $M$ et al. Complement factor $\mathrm{H}$ gene mutation associated with autosomal recessive atypical hemolytic uremic syndrome. Am J Hum Genet 1999; 65: 1538-1546.

4. Loos M. The complement system: activation and control. Curr Top Microbiol Immunol 1985; 121: 7-18.

5. Garred P, Honore C, Ma YJ et al. MBL2, FCN1, FCN2 and FCN3-The genes behind the initiation of the lectin pathway of complement. Mol Immunol 2009; 46: 2737-2744.

6. Roos A, Bouwman LH, van Gijlswijk-Janssen DJ et al. Human IgA activates the complement system via the mannan-binding lectin pathway. J Immunol 2001; 167: 2861-2868.

7. Law SK, Levine RP. Interaction between the third complement protein and cell surface macromolecules. Proc Natl Acad Sci 1977; 74: 2701-2705.

8. Podack ER, Biesecker G, Muller-Eberhard HJ. Membrane attack complex of complement: generation of high-affinity phospholipid binding sites by fusion of five hydrophilic plasma proteins. Proc Natl Acad Sci 1979; 76: 897-901.

9. Pangburn MK. Host recognition and target differentiation by factor $\mathrm{H}$, a regulator of the alternative pathway of complement. Immunopharmacology 2000; 49: 149-157.

10. Ruggenenti P, Noris M, Remuzzi G. Thrombotic microangiopathy, hemolytic uremic syndrome, and thrombotic thrombocytopenic purpura. Kidney Int 2001; 60: 831-846.

11. Besbas N, Karpman D, Landau D et al. A classification of hemolytic uremic syndrome and thrombotic thrombocytopenic purpura and related disorders. Kidney Int 2006; 70: 423-431.

12. Karpman D, Sartz L, Johnson S. Pathophysiology of typical hemolytic uremic syndrome. Semin Thromb Haemostas 2010; 36: 575-585.

13. Obrig TG, Karpman D. Shiga toxin pathogenesis: kidney complications and renal failure. Curr Topics Microbiol Immunol 2012; 357: 105-136.

14. Loirat C, Noris M, Fremeaux-Bacchi V. Complement and the atypical hemolytic uremic syndrome in children. Pediatr Nephrol 2008; 23: 1957-1972.

15. Furlan M, Robles R, Galbusera M et al. von Willebrand factor-cleaving protease in thrombotic thrombocytopenic purpura and the hemolyticuremic syndrome. N Engl J Med 1998; 339: 1578-1584.

16. Tsai HM, Lian EC. Antibodies to von Willebrand factor-cleaving protease in acute thrombotic thrombocytopenic purpura. N Engl J Med 1998; 339: 1585-1594.
17. Manuelian T, Hellwage J, Meri S et al. Mutations in factor $\mathrm{H}$ reduce binding affinity to $\mathrm{C} 3 \mathrm{~b}$ and heparin and surface attachment to endothelial cells in hemolytic uremic syndrome. J Clin Invest 2003; 111: 1181-1190.

18. Vaziri-Sani F, Holmberg L, Sjöholm AG et al. Phenotypic expression of factor $\mathrm{H}$ mutations in patients with atypical hemolytic uremic syndrome. Kidney Int 2006; 69: 981-988.

19. Ståhl AL, Vaziri-Sani F, Heinen S et al. Factor H dysfunction in patients with atypical hemolytic uremic syndrome contributes to complement deposition on platelets and their activation. Blood 2008; 111: 5307-5315.

20. Van de Kar NC, Monnens LA, Karmali MA et al. Tumor necrosis factor and interleukin-1 induce expression of the verocytotoxin receptor globotriaosylceramide on human endothelial cells: implications for the pathogenesis of the hemolytic uremic syndrome. Blood 1992; 80: 2755-2764.

21. Louise CB, Obrig TG. Shiga toxin-associated hemolytic-uremic syndrome: combined cytotoxic effects of Shiga toxin, interleukin-1 beta, and tumor necrosis factor alpha on human vascular endothelial cells in vitro. Infect Immun 1991; 59: 4173-4179.

22. Karpman D, Papadopoulou D, Nilsson K et al. Platelet activation by Shiga toxin and circulatory factors as a pathogenetic mechanism in the hemolytic uremic syndrome. Blood 2001; 97: 3100-3108.

23. Ruiz-Torres MP, Casiraghi F, Galbusera M et al. Complement activation: the missing link between ADAMTS-13 deficiency and microvascular thrombosis of thrombotic microangiopathies. Thromb Haemost 2005; 93: 443-452.

24. Platt JL, Vercellotti GM, Lindman BJ et al. Release of heparan sulfate from endothelial cells. Implications for pathogenesis of hyperacute rejection. J Exp Med 1990; 171: 1363-1368.

25. Bossi F, Peerschke EI, Ghebrehiwet B et al. Crosstalk between the complement and the kinin system in vascular permeability. Immunol Lett 2011; 140: $7-13$.

26. Nachman RL, Hajjar KA, Silverstein RL et al. Interleukin 1 induces endothelial cell synthesis of plasminogen activator inhibitor. J Exp Med 1986; 163: $1595-1600$.

27. Saadi S, Holzknecht RA, Patte CP et al. Complement-mediated regulation of tissue factor activity in endothelium. J Exp Med 1995; 182: 1807-1814.

28. Acosta J, Qin X, Halperin J. Complement and complement regulatory proteins as potential molecular targets for vascular diseases. Curr Pharm Des 2004; 10: 203-211.

29. Langeggen $H$, Pausa M, Johnson E et al. The endothelium is an extrahepatic site of synthesis of the seventh component of the complement system. Clin Exp Immunol 2000; 121: 69-76.

30. Lozada C, Levin RI, Huie $M$ et al. Identification of $\mathrm{Clq}$ as the heat-labile serum cofactor required for immune complexes to stimulate endothelial expression of the adhesion molecules E-selectin and intercellular and vascular cell adhesion molecules 1. Proc Natl Acad Sci USA 1995; 92: 8378-8382.

31. Kilgore KS, Shen JP, Miller BF et al. Enhancement by the complement membrane attack complex of tumor necrosis factor-alpha-induced endothelial cell expression of E-selectin and ICAM-1. J Immunol 1995; 155: 1434-1441.
32. Van den Berg RH, Faber-Krol MC, Sim RB et al. The first subcomponent of complement, $\mathrm{Clq}$, triggers the production of IL-8, IL-6, and monocyte chemoattractant peptide- 1 by human umbilical vein endothelial cells. J Immunol 1998; 161: 6924-6930.

33. Kilgore KS, Flory CM, Miller BF et al. The membrane attack complex of complement induces interleukin-8 and monocyte chemoattractant protein-1 secretion from human umbilical vein endothelial cells. Am J Pathol 1996; 149: 953-961.

34. Benzaquen LR, Nicholson-Weller A, Halperin JA. Terminal complement proteins $\mathrm{C} 5 \mathrm{~b}-9$ release basic fibroblast growth factor and platelet-derived growth factor from endothelial cells. J Exp Med 1994; 179: 985-992.

35. Fischetti F, Tedesco F. Cross-talk between the complement system and endothelial cells in physiologic conditions and in vascular diseases. Autoimmunity 2006; 39: 417-428.

36. Hamilton KK, Hattori R, Esmon CT et al. Complement proteins C5b-9 induce vesiculation of the endothelial plasma membrane and expose catalytic surface for assembly of the prothrombinase enzyme complex. J Biol Chem 1990; 265: 3809-3814

37. Monsinjon T, Gasque P, Chan P et al. Regulation by complement $\mathrm{C} 3 \mathrm{a}$ and $\mathrm{C} 5 \mathrm{a}$ anaphylatoxins of cytokine production in human umbilical vein endothelial cells. FASEB J 2003; 17: 1003-1014.

38. Kerr H, Richards A. Complement-mediated injury and protection of endothelium: lessons from atypical haemolytic uraemic syndrome. Immunobiology 2012; 217: 195-203.

39. Karpman D, Kahn R. The contact/kinin and complement systems in vasculitis. APMIS Suppl 2009: 48-54.

40. Bossi F, Fischetti F, Pellis V et al. Platelet-activating factor and kinin-dependent vascular leakage as a novel functional activity of the soluble terminal complement complex. J Immunol 2004; 173: 6921-6927.

41. Dobrina A, Pausa M, Fischetti F et al. Cytolytically inactive terminal complement complex causes transendothelial migration of polymorphonuclear leukocytes in vitro and in vivo. Blood 2002; 99: 185-192.

42. Morigi M, Galbusera M, Gastoldi S et al. Alternative pathway activation of complement by Shiga toxin promotes exuberant C3a formation that triggers microvascular thrombosis. J Immunol 2011; 187: 172-180.

43. Roumenina LT, Frimat M, Miller EC et al. A prevalent $\mathrm{C} 3$ mutation in aHUS patients causes a direct C3 convertase gain of function. Blood 2012; 119: 4182-4191.

44. Roumenina LT, Jablonski M, Hue C et al. Hyperfunctional C3 convertase leads to complement deposition on endothelial cells and contributes to atypical hemolytic uremic syndrome. Blood 2009; 114: 2837-2845.

45. Frenette PS, Johnson RC, Hynes RO et al. Platelets roll on stimulated endothelium in vivo: an interaction mediated by endothelial P-selectin. Proc Natl Acad Sci 1995; 92: 7450-7454.

46. Del Conde I, Cruz MA, Zhang H et al. Platelet activation leads to activation and propagation of the complement system. J Exp Med 2005; 201: 871-879. 
47. Karpman D, Manea M, Vaziri-Sani F et al. Platelet activation in hemolytic uremic syndrome. Semin Thromb Hemost 2006; 32: 128-145.

48. Endresen GK, Mellbye OJ. Studies on the binding of complement factor $\mathrm{C} 3$ to the surface of human blood platelets. Haemostasis 1984; 14: 269-280.

49. Sandvik T, Endresen GK, Forre O. Studies on the binding of complement factor $\mathrm{C} 4$ in human platelets. Complement activation by means of cold agglutinins. Int Arch Allergy Appl Immunol 1984; 74: 152-157.

50. Nunez D, Charriaut-Marlangue C, Barel M et al. Activation of human platelets through gp140, the C3d/EBV receptor (CR2). Eur J Immunol 1987; 17: 515-520.

51. Vik DP, Fearon DT. Cellular distribution of complement receptor type 4 (CR4): expression on human platelets. J Immunol 1987; 138: 254-258.

52. Cosgrove LJ, d'Apice AJ, Haddad A et al. CR3 receptor on platelets and its role in the prostaglandin metabolic pathway. Immunol Cell Biol 1987; 65 (Pt 6): 453-460.

53. Peerschke EI, Ghebrehiwet B. Platelet membrane receptors for the complement component C1q. Semin Hematol 1994; 31: 320-328.

54. Zimmerman TS, Kolb WP. Human platelet-initiated formation and uptake of the C5-9 complex of human complement. J Clin Invest 1976; 57: 203-211.

55. Polley MJ, Nachman RL. Human complement in thrombin-mediated platelet function: uptake of the C5b-9 complex. J Exp Med 1979; 150: 633-645.

56. Polley MJ, Nachman RL. Human platelet activation by C3a and C3a des-arg. J Exp Med 1983 158: 603-615.

57. Dixon RH, Rosse WF. Mechanism of complementmediated activation of human blood platelets in vitro: comparison of normal and paroxysmal nocturnal hemoglobinuria platelets. J Clin Invest 1977; 59: 360-368.

58. Nicholson-Weller A, March JP, Rosen CE et al. Surface membrane expression by human blood leukocytes and platelets of decay-accelerating factor, a regulatory protein of the complement system. Blood 1985; 65: 1237-1244.

59. Tschopp J, Jenne DE, Hertig S et al. Human megakaryocytes express clusterin and package it without apolipoprotein A-1 into alpha-granules. Blood 1993; 82: 118-125.

60. Yu GH, Holers VM, Seya T et al. Identification of a third component of complement-binding glycoprotein of human platelets. J Clin Invest 1986; 78: 494-501.

61. Morgan BP. Isolation and characterization of the complement-inhibiting protein CD59 antigen from platelet membranes. Biochem J 1992; 282 (Pt 2): 409-413.

62. Vaziri-Sani F, Hellwage J, Zipfel PF et al. Factor H binds to washed human platelets. J Thromb Haemost 2005; 3: 154-162.

63. Licht C, Pluthero FG, Li L et al. Platelet-associated complement factor $\mathrm{H}$ in healthy persons and patients with atypical HUS. Blood 2009; 114: 4538-4545.

64. Kenney DM, Davis AE, 3rd. Association of alternative complement pathway components with human blood platelets: secretion and localization of factor D and beta $1 \mathrm{H}$ Globulin. Clin Immunol Immunopathol 1981; 21: 351-363.
65. Ståhl AL, Svensson M, Morgelin M et al. Lipopolysaccharide from enterohemorrhagic Escherichia coli binds to platelets through TLR4 and CD62 and is detected on circulating platelets in patients with hemolytic uremic syndrome. Blood 2006; 108: 167-176.

66. Ståhl AL, Sartz L, Karpman D. Complement activation on platelet-leukocyte complexes and microparticles in enterohemorrhagic Escherichia coliinduced hemolytic uremic syndrome. Blood 2011; 117: 5503-5513.

67. Sartz L, Olin AI, Kristoffersson AC et al. A novel C3 mutation causing increased formation of the C3 convertase in familial atypical hemolytic uremic syndrome. J Immunol 2012; 188 : 2030-2037.

68. Dong JF, Moake JL, Nolasco L et al. ADAMTS-13 rapidly cleaves newly secreted ultralarge von Willebrand factor multimers on the endothelial surface under flowing conditions. Blood 2002; 100: 4033-4039.

69. Kelton JG, Warkentin TE, Hayward CP et al. Calpain activity in patients with thrombotic thrombocytopenic purpura is associated with platelet microparticles. Blood 1992; 80: 2246-2251.

70. Jimenez JJ, Jy W, Mauro LM et al. Elevated endothelial microparticles in thrombotic thrombocytopenic purpura: findings from brain and renal microvascular cell culture and patients with active disease. Br J Haematol 2001; 112: 81-90.

71. Williams JD, Czop JK, Abrahamson DR et al. Activation of the alternative complement pathway by isolated human glomerular basement membrane. J Immunol 1984; 133: 394-399.

72. Hindmarsh EJ, Marks RM. Complement activation occurs on subendothelial extracellular matrix in vitro and is initiated by retraction or removal of overlying endothelial cells. J Immunol 1998; 160: 6128-6136.

73. Bevan HS, Slater SC, Clarke H et al. Acute laminar shear stress reversibly increases human glomerular endothelial cell permeability via activation of endothelial nitric oxide synthase. Am J Physiol Renal Physiol 2011; 301: F733-F742.

74. Dong JF, Moake JL, Bernardo A et al. ADAMTS-13 metalloprotease interacts with the endothelial cell-derived ultra-large von Willebrand factor. J Biol Chem 2003; 278: 29633-29639.

75. Louise CB, Obrig TG. Specific interaction of Escherichia coli O157:H7-derived Shiga-like toxin II with human renal endothelial cells. J Infect Dis 1995; 172: 1397-1401.

76. Robson WL, Leung AK, Fick GH et al. Hypocomplementemia and leukocytosis in diarrhea-associated hemolytic uremic syndrome. Nephron 1992; 62: 296-299.

77. Thurman JM, Marians R, Emlen W et al. Alternative pathway of complement in children with diarrhea-associated hemolytic uremic syndrome. Clin J Am Soc Nephrol 2009; 4: 1920-1924.

78. Orth D, Khan AB, Naim A et al. Shiga toxin activates complement and binds factor $\mathrm{H}$ : evidence for an active role of complement in hemolytic uremic syndrome. J Immunol 2009; 182: 6394-6400.

79. Lapeyraque AL, Malina M, Fremeaux-Bacchi V et al. Eculizumab in severe Shiga-toxin-associated HUS. N Engl J Med 2011; 364: 2561-2563.

80. Menne J, Nitschke M, Stingele R et al. Validation of treatment strategies for enterohaemorrhagic
Escherichia coli O104:H4 induced haemolytic uraemic syndrome: case-control study. BMJ 2012; 345: e4565.

81. Kielstein JT, Beutel G, Fleig S et al. Best supportive care and therapeutic plasma exchange with or without eculizumab in Shiga-toxin-producing E. coli O104:H4 induced haemolytic-uraemic syndrome: an analysis of the German STEC-HUS registry. Nephrol Dial Transplant 2012; 27: 3807-3815

82. Loos S, Ahlenstiel T, Kranz B et al. An outbreak of Shiga toxin-producing Escherichia coli O104:H4 hemolytic uremic syndrome in Germany: presentation and short-term outcome in children. Clin Infect Dis 2012; 55: 753-759.

83. Delvaeye M, Noris M, De Vriese A et al. Thrombomodulin mutations in atypical hemolytic-uremic syndrome. N Engl J Med 2009; 361: 345-357.

84. Ståhl AL, Kristoffersson A, Olin AI et al. A novel mutation in the complement regulator clusterin in recurrent hemolytic uremic syndrome. Mol Immunol 2009; 46: 2236-2243.

85. Zipfel PF, Mache C, Muller D et al. DEAP-HUS: deficiency of CFHR plasma proteins and autoantibody-positive form of hemolytic uremic syndrome. Pediatr Nephrol; 2010: 25: 2009-2019.

86. Brackman D, Sartz L, Leh S et al. Thrombotic microangiopathy mimicking membranoproliferative glomerulonephritis. Nephrol Dial Transplant 2011; 26: 3399-3403.

87. Zuber J, Fakhouri F, Roumenina LT et al. Use of eculizumab for atypical haemolytic uraemic syndrome and C3 glomerulopathies. Nat Rev Nephrol 2012; 8: 643-657.

88. Zuber J, Le Quintrec M, Krid S et al. Eculizumab for atypical hemolytic uremic syndrome recurrence in renal transplantation. Am J Transplant 2012; 12: 3337-3354.

89. Crawley JT, de Groot R, Xiang Y et al. Unraveling the scissile bond: how ADAMTS13 recognizes and cleaves von Willebrand factor. Blood 2011; 118: 3212-3221.

90. Reti M, Farkas P, Csuka D et al. Complement activation in thrombotic thrombocytopenic purpura. J Thromb Haemost 2012; 10: 791-798.

91. Noris M, Ruggenenti P, Perna A et al. Hypocomplementemia discloses genetic predisposition to hemolytic uremic syndrome and thrombotic thrombocytopenic purpura: role of factor $\mathrm{H}$ abnormalities. Italian Registry of Familial and Recurrent Hemolytic Uremic Syndrome/Thrombotic Thrombocytopenic Purpura. J Am Soc Nephrol 1999; 10: 281-293.

92. Mant MJ, Cauchi MN, Medley G. Thrombotic thrombocytopenic purpura: report of a case with possible immune etiology. Blood 1972; 40: 416-421.

93. Weisenburger DD, O'Conner ML, Hart MN Thrombotic thrombocytopenic purpura with C'3 vascular deposits: report of a case. Am J Clin Pathol 1977; 67: 61-63.

94. Chapin J, Weksler B, Magro C et al. Eculizumab in the treatment of refractory idiopathic thrombotic thrombocytopenic purpura. Br J Haematol; 157: 772-774.

95. Walport MJ. Complement. First of two parts. N Engl J Med 2001; 344: 1058-1066.

96. Heinen S, Hartmann A, Lauer N et al. Factor H-related protein 1 (CFHR-1) inhibits complement C5 
convertase activity and terminal complex formation. Blood 2009; 114: 2439-2447.

97. Nilsson SC, Sim RB, Lea SM et al. Complement factor I in health and disease. Mol Immunol 2011; 48: 1611-1620.

98. Cardone J, Le Friec G, Kemper C. CD46 in innate and adaptive immunity: an update. Clin Exp Immunol 2011; 164: 301-311.

99. Seya T, Okada M, Matsumoto M et al. Preferential inactivation of the $\mathrm{C} 5$ convertase of the alternative complement pathway by factor I and membrane cofactor protein (MCP). Mol Immunol 1991; 28: 1137-1147.

100. Conway EM. Thrombomodulin and its role in in flammation. Semin Immunopathol 2012; 34: 107-125.
101. Petersen SV, Thiel S, Jensen L et al. Control of the classical and the MBL pathway of complement activation. Mol Immunol 2000; 37: 803-811.

102. Gigli I, Fujita T, Nussenzweig V. Modulation of the classical pathway $\mathrm{C} 3$ convertase by plasma proteins $\mathrm{C} 4$ binding protein and $\mathrm{C} 3 \mathrm{~b}$ inactivator. Proc Natl Acad Sci USA 1979; 76: 6596-6600.

103. Medof ME, Iida K, Mold C et al. Unique role of the complement receptor CR1 in the degradation of C3b associated with immune complexes. J Exp Med 1982; 156: 1739-1754.

104. Medof ME, Kinoshita T, Nussenzweig V. Inhibition of complement activation on the surface of cells after incorporation of decay-accelerating factor (DAF) into their membranes. J Exp Med 1984; 160: 1558-1578.

105. Podack ER, Preissner KT, Muller-Eberhard HJ. Inhibition of $\mathrm{C} 9$ polymerization within the
SC5b-9 complex of complement by S-protein. Acta Pathol Microbiol Immunol Scand Suppl 1984; 284: 89-96.

106. Davies A, Simmons DL, Hale G et al. CD59, an LY-6-like protein expressed in human lymphoid cells, regulates the action of the complement membrane attack complex on homologous cells. J Exp Med 1989; 170: 637-654.

107. Bokisch VA, Muller-Eberhard HJ. Anaphylatoxin inactivator of human plasma: its isolation and characterization as a carboxypeptidase. J Clin Invest 1970; 49: 2427-2436. 